\begin{tabular}{l}
\hline SPORTIVE: Journal of Physical Education, Sport and Recreation \\
Volume 1 Nomor 1 September 2017 \\
e-ISSN: $2597-7016$ dan p-ISSN: $2595-4055$ \\
@) (1) This work is licensed under a Creative Commons Attribution \\
4.0 International License
\end{tabular}

\title{
Pengaruh Tingkat Kebugaran Jasmani Terhadap Prestasi Kerja Pegawai Negeri Sipil TNI AU Pada MAKOOPSAU II Makassar
}

\section{Muhammad Bahtiar, Djen Djalal, Suwardi}

\author{
Keywords : \\ Tingkat Kebugaran; \\ Jasmani; \\ Prestasi kerja.

\section{Corespondensi Author \\ ${ }^{1}$ Universitas Negeri Makassar, Email: \\ perwiraksatria94@yahoo.com}

\section{Article History}

Received: 10-08-2017;

Reviewed: 20-08-2017;

Accepted: 20-09-2017;

Published: 27-09-2017

\begin{abstract}
Tujuan penelitian ini adalah mengetahui Pengaruh tingkat kesegaran jasmani terhadap prestasi kerja PNS TNI AU Koopsau II di Makassar. Jenis penelitian deskriptif yang menggunakan rancangan penelitian "korelasional". Penelitian ini bertujuan untuk mengetahui: Pengaruh tingkat kesegaran jasmani terhadap prestasi kerja PNS TNI AU Koopsau II di Makassar. Populasinya adalah Keseluruhan PNS TNI AU Koopsau II di Makassar. Teknik penentuan sampel adalah dengan teknik sampling jenuh yaitu semua anggota populasi PNS TNI AU Koopsau II di Makassar digunakan sebagai sampel sebanyak 58 sampel. Teknik analisis data yang digunakan adalah analisis deskriptif, analisis koefisien korelasi Pearson Product Moment (r), analisis regresi dan analisis korelasi ganda (R) melalui program SPSS 21 pada taraf signifikan $\alpha 0,05$. Hasil penelitian menunjukkan bahwa; Hasil penelitian menunjukkan bahwa: Diperoleh data hasil penelitian sebesar 0,209 berarti kesegaran jasmani memberikan sumbangan sebesar 20,9\% terhadap prestasi kerja PNS TNI AU, dan sisanya sebesar 79,1\% dipengaruhi faktor lain.
\end{abstract}

\section{PENDAHULUAN}

Untuk mencapai prestasi kerja PNS ini harus didukung dengan tingkat kesegaran jasmani seseorang apalagi tuntutan beban kerja yang menumpuk dan kurangnya ruang gerak dalam kegiatan sehari - hari. Kesegaran jasmani merupakan aspek yang sangat penting dari kesegaran tubuh secara keseluruhan yang memberikan kesanggupan pada seseorang untuk menjalani hidup yang produktif serta dapat menyesuaikan diri setiap beban fisik yang layak. Seorang PNS yang memiliki tingkat kesegaran jasmani yang tinggi atau tingkat kondisi tubuh yang prima akan dapat melakukan aktifitas kesehariannya dengan baik dalam waktu yang cukup lama, tanpa mengalami kelelahan yang berarti.

Kesegaran jasmani merupakan aspek yang sangat penting dari kesegaran tubuh secara keseluruhannya yang memberikan kesanggupan pada seorang PNS dapat bertahan untuk melakukan pekerjaan baik didalam kantor maupun diluar kantor mereka tidak cepat lelah untuk menjalani hidup yang produktif serta dapat menyesuaikan diri setiap beban fisik yang layak. Karena itu, tingkat kesegaran jasmani yang dijadikan sebagai pegangan utama dan sangat menentukan hasil pencapaian prestasi yang diharapkan. 
Penilaian prestasi kerja PNS secara strategis diarahkan sebagai pengendalian perilaku kerja produktif yang disyaratkan untuk mencapai hasil kerja yang disepakati dan bukan penilaian atas kepribadian seseorang PNS.Unsur perilaku kerja yang mempengaruhi prestasi kerja yang dievaluasi harus relevan dan berhubungan dengan pelaksanaan tugas pekerjaan dalam jenjang jabatan setiap PNS yang dinilai.

Dari hasil tersebut, suatu organisasi dapat mengembangkan suatu perencanaan sumber daya manusia secara menyeluruh dilihat dari segi tingkat kesegaran jasmani dalam menghadapi masa depan serta tantangan yang dihadapi oleh PNS dalam menyelesaikan beban tugas yang diberikan. Perencanaan sumber daya manusia secara menyeluruh tersebut berupa peningkatan kesegaran jasmani para PNS.

Berangkat dari dasar penilaian ditinjau dari segi tingkat kesegaran jasmani ini, peneliti tertarik untuk melakukan sebuat kajian ilmiah melalui sebuah penelitian dengan judul “ Pengaruhtingkat kesegaran jasmani terhadap prestasi kerja PNS TNI AU Koopsau II di Makassar".. Hipotesis penelitian adalah "Terdapat pengaruh tingkat kesegaran jasmani terhadap prestasi kerjaPNS TNI AU Koopsau II di Makassar"

Penilaian prestasi kerja ini pada dasarnya merupakan salah satu faktor kunci guna mengembangkan suatu instansisecara efektif dan efesien.Penilaian prestasi kerja juga memungkinkan para PNS untuk mengetahui bagaimana prestasi kerja mereka, dan sejauh mana hasil kerja mereka dinilai oleh atasan. Prestasi kerja adalah hasil kerja yang dicapai oleh seseorang atau sekelompok orang dalam suatu instansi,sesuai dengan wewenang dan tanggung jawab masing-masing dalam rangka upaya mencapai tujuan organisasi bersangkutan secara legal, tidak melanggar hukum dan sesuai dengan moral atau etika.

Menurut Dessler(2008:290) penilaian prestasi kerja adalah suatu proseduryang mengaitkan pengaturan standar kerja,mengukur kinerja terkini dari karyawan yang dibandingkan dengan standar dan memberi timbal balik pada karyawan dengan tujuan untuk memotivasi karyawan dan menghilangkan kinerja yang buruk atau melanjutkan kinerja yang sudah baik.

Hambatan-hambatan dalam penilaian prestasi kerja. T.Hani Handoko (1995:140-141) mengatatakan bahwa ada 5 (lima) kendala dalam melakukan penilaian kinerja, yaitu:

1) Halo Effect maksudnya adalah kendala ini muncul ketika orang yang menilai memiliki hubungan dengan karyawan yang dinilai

2) Kesalahan Kecenderungan Terpusat maksudnya adalah penilai terkadang tidak merasa nyaman memberikan penilaian yang terlalu baik

3) Bias Terlalu Lunak dan Terlalu Keras maksudnya adalah bila standar penilaian prestasi tidak jelas maka akan muncul kecenderungan penilai memberikan penilaian yang terlalu lunak maupun penilaian yang terlalu ketat.

4) Prasangka Pribadi maksudnya adalah faktor-faktor yang membentuk prasangka pribadi terhadap seorang atau kelompok bisa mengubah penilaian.

5) Pengaruh Kesan Terakhir maksudnya adalahpesan terakhir terkadang memberikan pengaruh yang domonan dalam proses penilaian.

Hasibuan (2003:91), menyatakan bah wa seorang penilai yang baik harus memiliki sya rat-syarat sebagai berikut:

1. Untuk mendapatkan penilaian yang jujur, adil dan objektif maka penilai haruslah orang yang mengerti tentang faktor-faktor yang menjadi indikator penilaian.

2. Penilai harus tegas dan hendaknya mendasarkan penilaiannya pada benar atau salah, baik atau buruknya terhadap unsurunsur yang dinilai sehingga penilaiannya jujur, adil, dan objektif.

3. Penilai harus mempunyai authority (kewenangan) formal supaya mereka dapat melaksanakan tugasnya dengan baik.

Unsur-unsur yang dinilai. Menurut Hasibu an (2003:194), unsur yang dinilai dalam melaku kan penilaian prestasi adalah kesetiaan karyawa $\mathrm{n}$ terhadap pekerjaan, jabatan dan organisasi, has il kerja karyawan baik kualitas maupun kuantita s yang sesuai dengan jabatannya, kejujuran dala m melaksanakan tugas-tugas yang diberikan kep adanya dan kedisiplinan karyawan dalam mema hami peraturan yang telah ditetapkan.

Tujuan dan manfaat penilaian prestasi kerja. Penilaian prestasi kerja bertujuan untuk menget ahui tingkat efektivitas dalam mempekerjakan $\mathrm{P}$ NS, serta peranan PNS tersebut dalam mencapai tujuan instansi. Tujuan laindari penilaian prestas i kerja PNS adalah, memberikan informasi bagi 
mana jemeninstansi dalam pengambilan keputus an yang berkaitan dengan PNS, misalnya promo si jabatan.

Daftar Penilaian Pelaksanaan Pekerjaan atau DP3 adalah penilaian yang diberikan atasan bertujuan untuk memperoleh bahanbahan pertimbangan yang obyektif dalam pembinaan PNS, dan dilaksanakan dalam kurun waktu sekali setahun oleh pejabat penilai, yang dituangkan dalam daftar Penilaian Pelaksanaan pekerjaan (DP3).

Kesegaran jasmani dikenal dengan istilah asing "physical fitness." Physical berarti badan atau tubuh sedangkan fitness berarti segar. Jadi yang dimaksud dengan physical fitness (kesegaran jasmani) yaitu badan yang sehat dan segar. Pengertian kesegaran jasmani dipandang sebagi suatu konsep yang mempunyai ruang lingkup yang cukup luas. kesegaran jasmani adalah kesanggupan tubuh untuk melakukan aktivitas tanpa mengalami kelelahan yang berarti. Orang yang bugar berarti ia tidak gampang lelah dan capek. Demikian juga para PNS dilingkup TNI AU Koopsau II membutuhkan tingkat kesegaran jasmani yang lebih baik untuk dapat melaksanakan proses kerja dengan baik. Kesemuanya bisa tercapai dengan baik, jika kita melaksanakan aktifitas pendidikan jasmani dan olahraga seperti melakukan kegiatan aktivitas atletik, senam serta didukung oleh motivasi kerja dengan baik dan rutin khususnya pada PNS dilingkup Koopsau II Makassar.

Profil Koopsau II. Komando Operasi An gkatan Udara II atau disingkat Koops AU II adal ah salah satu Komando OperasiTNI Angkatan U dara yang mencakup wilayah Indonesia bagian ti mur yang meliputi seluruh Sulawesi, Kalimanta $\underline{\text { n Timur, sebagian Kalimantan Tengah, Kaliman }}$ tan Selatan, Jawa Timur, Bali, Nusa Tenggara, Maluku, sebagian Jawa Tengah dan Papua. Koo psau II bermarkas di Makassar, Sulawesi Selatan Komando ini mempunyai tugas yaitu pembinaa $\mathrm{n}$ kemampuan dan kesiapsiagaan operasional sat uan-satuan TNI AU dalam jajarannya, dan mela ksanakan operasi-operasi udara dalam rangka pe negakan kedaulatan negara di udara, mendukung penegakan kedaulatan negara di darat dan di lau t.

\section{METODE PENELITIAN}

Jenis penelitian ini adalah jenis deskripti $\mathrm{f}$, jenis analisis data yaitu dengan cara menganili sis data kuantitatif yang diperjelas dari hasil pen elitian berupa data dan informasi mengenai per masalahan yang dibahas. Penelitian ini menggun akan metode penelitian lapangan, yaitu: peneliti an lapangan, sedangkan lokasi Penelitian ini dila ksanakan ditingkat kesegaran jasmani dan presta si kerja PNS TNI AU Koopsau II di Makassar.

Variabel bebas dalam penelitian ini adal ah Tingkat Kesegaran Jasmani (X1), sedangkan variabel terikat adalah prestasi kerja $(\mathrm{Y})$. Variab el-variabel tersebut dapat didefinisikan secara op erasional sebagai berikut:

1. Tingkat kesegaran jasmani (X1) yang dimaksud dalam penelitian ini yaitu kemampuan seseorang untuk melakukan suatu kegiatan sehari- hari dalam waktu tertentu tanpa mengalami kelelahan yang berarti dan orang tersebut masih mempunyai cadangan tenaga untuk melakukan suatu kegiatan. Untuk mengetahui tingkat kesegaran jasmani ini peneliti hanya melakukan tes lari selama $2,4 \mathrm{~km}$.

2. Prestasi kerja (Y) dalam hal ini yaitu penilaian terhadap Pegawai Negeri Sipil melalui Hasil Penilaian pelaksanaan pekerjaan PNS, dituangkan dalam Daftar Penilaian Pelaksanaan Pekerjaan (DP3).

Populasi menurut Sugiyono (2011:119) adalah wilayah generalisasi yang terdiri atas: obyek/subyek yang mempunyai kualitas dan karalteristik tertentu yang ditetapkan oleh peneliti untuk dipelajari dan kemudian ditarik kesimpulannya, maka yang menjadi populasi dalam penelitian ini adalah keseluruhan PNS TNI AU Koopsau II di Makassar yaitu berjumlah 58 orang pria dan wanita.Pemilihan sampel tersebut menggunakan tekniksamplingjenuh yaitu semua anggota populasi PNS TNI AU Koopsau II di Makassar digunakan sebagai sampel.

Pengumpulan data dilakukan untuk memperolah data empirik sebagai bahan untuk menguji kebenaran hipotesis. Data yang dikumpulkan dalam penelitian ini meliputi :Tes tingkat kesegaran jasmani dan prestasi kerja PNS TNI AU Koopsau II di Makassar melalui Daftar Penilaian Pelaksanaan Pegawai (DP3).

\section{Tes tingkat kesegaran jasmanibagi PNS AU Pria dan Wanita}

Faktor yang menjadi bahan pertimbangan peneliti menggunakan tes kesegaran jasmani PNS pria dan Wanita dibagi 
menjadi 2 (dua) kelompok yaitu kelompok umur dibawah 45 tahun dan 45 tahun keatas yaitu sebagai berikut:

a. PNS pria dan wanita kelompok umur dibawah 25 tahun melaksanakan tes kesegaran jasmani A : lari 2400 meter.

b. PNS pria dan wanita kelompok umur diatas 25 tahun melaksanakan tes kesegaran jasmani B : lari 2400 meter atau jalan kaki 5000 meter.

c. Petunjuk penilaian tes kesegaran jasmani PNS pria dan wanita mengacu pada juklak Kemenhan RI Nomor juklak/08/08/2011 tanggal 2 Desember 2011 tentang penyelenggaraan tes kesegaran jasmani PNS kementerian pertahanan.

Tes Lari $2,4 \mathrm{~km}$

a. Tujuan : Untuk mengukur daya tahan jantung, peredaran darah dan pernapasan.

b. Alat/fasilitas: Lintasan lari, stopwatch, bendera start, sumpritan, tiang pancang, formulir tes dan alat tulis.

c. Petugas tes: Petugas keberangkatan, pengukur waktu, pencatat hasil, dan pembantu umum.

d. Kegiatan:

1) Sikap permulaan: peserta berdiri di belakang garis start;

2) Gerakan pada aba-aba "siap" peserta berdiri mengambil sikap start berdiri, siap untuk berlari;

3) Pada aba-aba "ya" peserta lari menuju garis finish, menempuh jarak 1200 meter;

4) Lari diulang bila ada pelari yang mencuri start dan tidak melewati garis finish.

\section{HASIL PENELITIAN}

Analisis deskriptif dilakukan terhadap Tingkat Kesegaran Jasmaniterhadap prestasi kerjaPNS TNI AU Koopsau II di Makassar. Hal ini dimaksudkan untuk memberi makna pada hasil analisis yang telah dilakukan. Hasil analisis deskriptif data tersebut dapat dilihat pada tabel 1.

Tabel 4.1. Rangkuman hasil analisis deskriptif data Tingkat Kesegaran Jasmaniterhadap prestasi kerjaPNS TNI AU Koopsau II di Makassar

\begin{tabular}{|c|c|c|}
\hline $\begin{array}{c}\text { Nilai } \\
\text { Statistik }\end{array}$ & $\begin{array}{c}\text { Tingkat } \\
\text { Kesegaran } \\
\text { Jasmani }\end{array}$ & $\begin{array}{c}\text { Prestasi } \\
\text { Kerja }\end{array}$ \\
\hline $\mathrm{N}$ & 58 & 58 \\
\hline Sum & 3815,00 & 4698,29 \\
\hline
\end{tabular}

\begin{tabular}{ccc}
\hline Mean & 65,776 & 81,005 \\
SD & 10,026 & 6,310 \\
Varians & 100,528 & 39,820 \\
Range & 47,00 & 32,20 \\
Minimum & 41,00 & 62,33 \\
Maksimum & 88,00 & 94,53 \\
\hline
\end{tabular}

Tabel 1 di atas merupakan gambaran data Tingkat Kesegaran Jasmaniterhadap prestasi kerjaPNS TNI AU Koopsau II di Makassar.

Tabel 4.2.Deskripsi Hasil Penelitian Tingkat Kesegaran Jasmani

\begin{tabular}{|c|c|c|c|}
\hline $\mathrm{NO}$ & KLASIFIKASI & FREKUENSI & $\%$ \\
\hline \multirow{2}{*}{1} & BAIK & & \\
\hline & SEKALI & 4 & 6,9 \\
\hline 2 & BAIK & 37 & 63,79 \\
\hline 3 & CUKUP & 17 & 29,31 \\
\hline 4 & KURANG & 0 & 0 \\
\hline \multirow{3}{*}{5} & KURANG & & \\
\hline & SEKALI & 0 & 0 \\
\hline & JUMLAH & 58 & 100 \\
\hline
\end{tabular}

Tabel 4.3. Deskripsi Hasil Penelitian Prestasi Kerja

\begin{tabular}{clcc}
\hline NO & KLASIFIKASI & FREKUENSI & $\%$ \\
\hline \multirow{2}{*}{1} & SANGAT & & \\
2 & BAIK & 1 & 1,72 \\
2 & BAIK & 45 & 77,59 \\
3 & CUKUP & 12 & 20,69 \\
4 & KURANG & 0 & 0 \\
5 & KURANG & & \\
& SEKALI & 0 & 0 \\
\hline & JUMLAH & 58 & 100 \\
\hline
\end{tabular}

Untuk mengetahui apakah data Tingkat Kesegaran Jasmaniterhadap prestasi kerjaPNS TNI AU Koopsau II di Makassar berdistribusi normal, maka dilakukan uji normalitas data dengan menggunakan uji Kolmogorov Smirnov. Hasil uji normalitas dapat dilihat pada Tabel 4. berikut ini:

Tabel 4.4. Rangkuman hasil Uji normalitas data Tingkat Kesegaran Jasmaniterhadap prestasi kerjaPNS TNI AU Koopsau II di Makassar.

\begin{tabular}{ccc}
\hline Nilai & Tingkat & \\
Statistik & Kesegaran & Prestasi Kerja \\
& Jasmani & \\
\hline
\end{tabular}




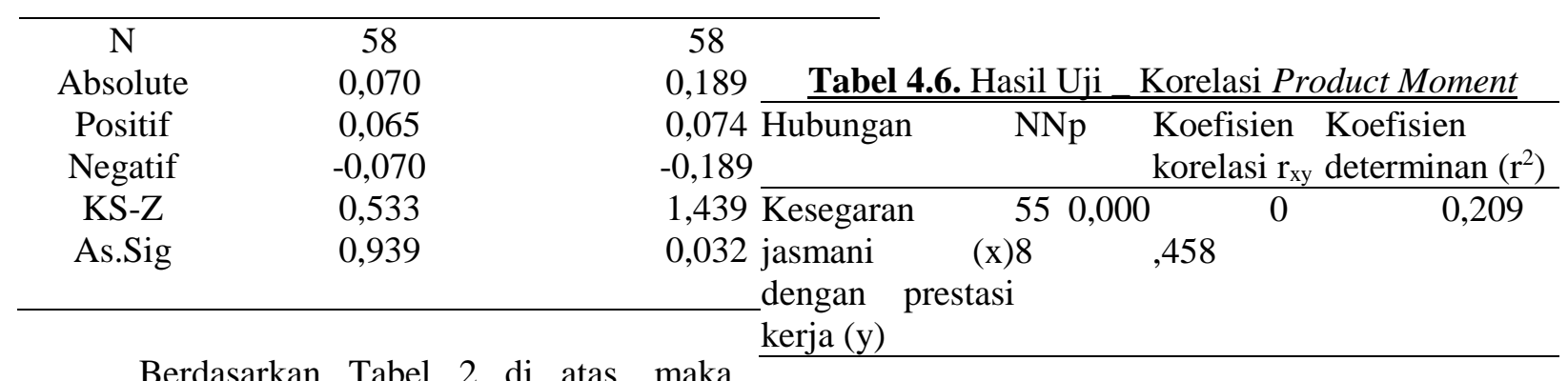
pengujian normalitas data dengan menggunakan uji Kolmogrov-Smirnov (KS-Z) menunjukkan hasil sebagai berikut:

1. Untuk data tingkat kesegaran jasmani, diperoleh nilai $\mathrm{KS}-\mathrm{Z}=0,533 \quad(\mathrm{P}=$ $0,939>\alpha 0,05)$, sehingga dapat disimpulkan bahwa data tingkat kesegaran jasmani mengikuti sebaran normal atau berdistribusi normal.

2. Untuk data prestasi kerja, diperoleh nilai $\mathrm{KS}-\mathrm{Z}=1,439(\mathrm{P}=0,032>\alpha 0,05)$, sehingga dapat disimpulkan bahwa data prestasi kerja mengikuti sebaran normal atau berdistribusi normal.

Tujuan uji linieritas adalah untuk mengetahui hubungan antara variabel bebas dan variabel terikat linier atau tidak. Kriteria pengujian linearitas adalah jika $\mathrm{f}_{\text {hi }} \mathrm{t}<\mathrm{t}$ tab dan harga $\mathrm{p}$ (probabilitas) > 0,05 (sig $5 \%$ ),maka hubungan antara variabel bebas dan variabel terikat adalah linier. Sebaliknya apabila $\mathrm{f}_{\text {hi }}>\mathrm{f}$ $\mathrm{ta}_{\mathrm{b}}$ dan nilai $\mathrm{p}$ (probabilitas) $<0,05$ (sig $5 \%$ ) dinyatakan tidak linier. Hasil rangkuman uji linearitas disajikan pada tabel berikut ini:

Tabel 4.5. Hasil Uji Linearitas

\begin{tabular}{lllllll}
\hline Hubungan & Df & $\begin{array}{l}\mathrm{F} \\
\text { Tabel }\end{array}$ & $\begin{array}{l}\mathrm{F} \\
\text { Hit }\end{array}$ & $\begin{array}{l}\text { sig } \\
\%\end{array}$ & 5 \\
\hline Hubungan & $1: 5$ & 4,01 & 0,37 & 0,99 & 0,05 & L \\
(X) & 6 & & 0 & 4 & & r \\
dengan & & & & & & \\
(Y) & & & & & & \\
\hline
\end{tabular}

Hasil uji linieritas diatas menunjukkanhubungan $\mathrm{X}$ dengan $\mathrm{Y}$ diperoleh $\mathrm{f}$ hit $(0,370)<\mathrm{f}$ tab $(4,01)$ dan $p(0,994)>0,05$, berarti hubungan antara variabel tingkat kesegaran jasmani dan prestasi kerja adalah linier.

Untuk menguji hubungan antara kesegaran jasmani (X) dengan prestasi belajar (Y) menggunakan uji korelasi product moment dari Karl Person. Hasil uji korelasi dapat diuraikan sebagai berikut:
Dari hasil perhitungan yang diperoleh nilai $r$ hit $(0,458)>p(0,000)$ artinya ada hubungan yang signifikan antara tingkat kesegaran jasmani dengan prestasi kerja PNSTNI AU Koopsau II di Makassar.

Dari hasil korelasi dapat diperoleh nilai koefisien determinan $\left(\mathrm{R}^{2}\right)$ variabel $(0,209)$.Nilai koefisien determinan dikalikan 100, merupakan suatu alat untuk mengukur besarnya persentase pengaruh variabel bebas terhadap variabel terikat. Dengan demikian nilai koefisien determinan $(\mathrm{R})$ diperoleh sebesar 0,209 X 100 $=20,9 \%$. Berarti tingkat kesegaran jasmani memberikan sumbangan sebesar 20,9 \% terhadap prestasi kerja PNS TNI AU Koopsau II di Makassar, sisanya sebesar 79,1\% dipengaruhi faktor lain (Sugiyono, 2006: 250).

Berdasarkan tabel dan gambar di atas diketahui tingkat kesegaran jasmani PNS sebagian besar berada pada kategori cukup sebanyak 63,79 \%. Hasil tersebut diartikan tingkat kesegaran jasmani PNSTNI AU Koopsau II di Makassar adalah baik.Dari hasil di atas dapat diartikan bahwa kesegaran jasmani berhubungan kondisi fisik seseorang.Kesegaran jasmani merupakan kemampuan tubuh dEseorang untuk melakukan tugas dan pekerjaan sehari- hari tanpa menimbulkan kelalahan yang Lbiararti, sehingga tubuh masih memiliki rsimpanan tenaga untuk mengatasi beban kerja tambahan. Dalam hal ini hubungan kesegaran jasmani dengan prestasi kerja terhadap suatu pekerjaan dikantor merupakan hubungan tidak langsung, artinya dengan kebugaran jasmani yang baik pegawai/ karyawan dalam hal ini PNS TNI AU Koopsau di Makassar dapat dengan baik melakukan aktivitas jasmani, dengan demikian akan mendukung pencapaian prestasi kerja.

\section{SIMPULAN DAN SARAN}

Berdasarkan analisis data dan pembahasan pada bab sebelumya, dapat 
disimpulkan ada hubungan yang signifikan antara tingkat kesegaran jasmani dan prestasi kerja. Artinya dapat disimpulkan ada hubungan yang signifikan antara tingkat kesegaran jasmani dan prestasi kerja PNS TNI AU Koopsau II di Makassar. Hasil koefisien ( R) diperoleh sebesar 0,209 berarti kesegaran jasmani memberikan sumbangan sebesar 20,9\% terhadap prestasi kerja PNS TNI AU, dan sisanya sebesar 79,1\% dipengaruhi faktor lain.

Hasil penelitian ini mempunyai implikasi sebagai berikut: (1) Menjadi masukan dan referensi bagi PNS TNI AU Koopsau II di Makassar mengenai data kesegaran jasmani dan prestasi kerja. (2) Para pemangku kebijakan di TNI AU Koopsau II semakin paham tentang faktor-faktor yang dapat mendukung prestasi kerja para anggotanya. Dengan demikian dapat ditetapkan sebagai salah satu faktor-faktor yang memengaruhi prestasi kerja dan menjadi referensi untuk TNI AU Koopsau II di Makassar agar selalu memperhatikan kesegaran jasmani untuk meningkatkan prestasi kerja anggotanya dalam hal ini para PNS TNI AU Koopsau II di Makassar

\section{DAFTAR RUJUKAN}

Sugiyono. 2006.Metode Penelitian Pendidikan, Pendekatan Kuantitatif, Kualitatif dan $R \&$.Bandung: Alfabeta.

Sugiyono. 2008. Statistika Untuk Penelitian, Bandung: Alfabeta.

Sugiyono . 2013. Metode Penelitian Pendidikan, Pendekatan Kuantitatif, Kualitatif dan $R \& D$.Bandung: Alfabeta.

Sukadiyanto dan Muluk, Dangsina.2011.Pengantar Teori dan Metodologi Melatih Fisik.Bandung: Lubuk Agung.

TNI AU, 2013.Buku Petunjuk Teknis AU tentang Uji Kesamaptaan Jasmani. Jakarta.

Widiastuti. 2011. Tes dan Pengukuran Olahraga.Jakarta Timur: Bumi Timur Jaya.
Dessler, Gary. 2008. Manajemen Sumber Daya Manusia Jilid II. Jakarta: PT. Prenhalindo.

Handoko, T. Hani. 1999. Manejemen SDM. Yogyakarta: BPFE.

Handoko, T. Hani, 2000.Manajemen Personalia Dan Sumber Daya Manusia.Yogyakarta:BPFE.

Harsono. 1988.Coaching dan Aspek-Aspek Psikologis dalam coaching, Jakarta: Tambak Kusuma.

Hasibuan, Malayu. 2003. Manajemen SDM Edisi Revisi. Jakarta: PT. Bumi Aksara. 